\title{
Erratum to fibroblast activation protein $\alpha$-positive pancreatic stellate cells promote the migration and invasion of pancreatic cancer by CXCL1-mediated Akt phosphorylation
}

\section{Editorial Office}

Annals of Translational Medicine

Correspondence to: Editorial Office. Annals of Translational Medicine. Email: editor@atmjournal.org.

Submitted Sep 07, 2021. Accepted for publication Sep 14, 2021.

doi: 10.21037/atm-2021-29

View this article at: https://dx.doi.org/10.21037/atm-2021-29

Erratum to: Ann Transl Med 2019;7:532

In the published paper entitled "Fibroblast activation protein $\alpha$-positive pancreatic stellate cells promote the migration and invasion of pancreatic cancer by CXCL1-mediated Akt phosphorylation" (1), there was an unintentional error of Figure 3C-BxPC3 [FAPa (+) PCSs + PT100], which would not affect or change the final results or conclusions. To fix this error, a correction with right figure is presented as follows.

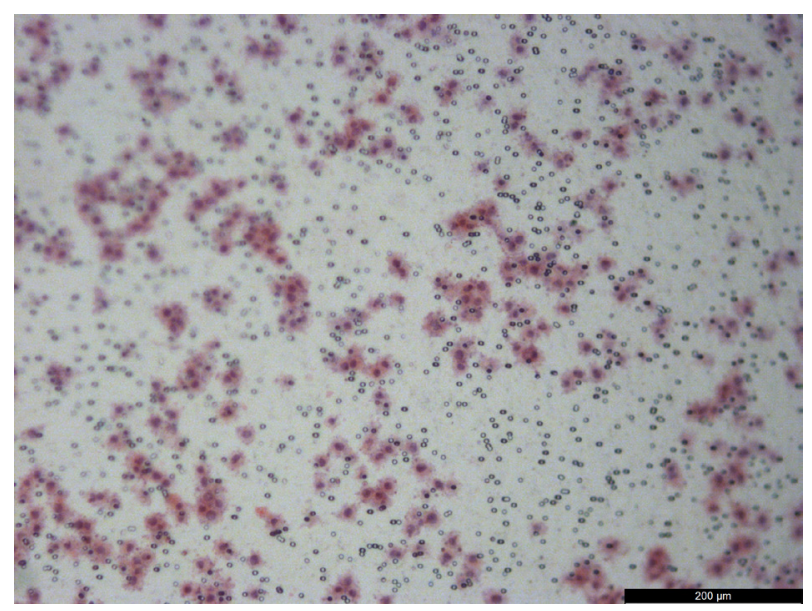

Click here to view the updated version of the article.

Open Access Statement: This is an Open Access article distributed in accordance with the Creative Commons AttributionNonCommercial-NoDerivs 4.0 International License (CC BY-NC-ND 4.0), which permits the non-commercial replication and distribution of the article with the strict proviso that no changes or edits are made and the original work is properly cited (including links to both the formal publication through the relevant DOI and the license). See: https://creativecommons.org/ licenses/by-nc-nd/4.0/. 
Page 2 of 2

\section{References}

1. Wen $\mathrm{Z}$, Liu $\mathrm{Q}, \mathrm{Wu} \mathrm{J}$, et al. Fibroblast activation protein $\alpha$-positive pancreatic stellate cells promote the migration and invasion of pancreatic cancer by CXCL1-mediated Akt phosphorylation. Ann Transl Med 2019;7:532.

Cite this article as: Editorial Office. Erratum to fibroblast activation protein $\alpha$-positive pancreatic stellate cells promote the migration and invasion of pancreatic cancer by CXCL1-mediated Akt phosphorylation. Ann Transl Med 2021;9(19):1511. doi: 10.21037/atm-2021-29 